\author{
I. O. VAKULENKO ${ }^{1 *}$, S. O. PLITCHENKO ${ }^{2}$, D. M. MAKAREVICH ${ }^{3}$ \\ ${ }^{1 *}$ Dep. «Materials Technology», Dnipropetrovsk National University of Railway Transport named after Academician \\ V. Lazaryan, Lazaryan St., 2, Dnipropetrovsk, Ukraine, 49010, tel. +38 (056) 373 15 56, e-mail dnuzt_texmat@ukr.net, \\ ORCID 0000-0002-7353-1916 \\ ${ }^{2}$ Dep. «Materials Technology», Dnipropetrovsk National University of Railway Transport named after Academician \\ V. Lazaryan, Lazaryan St., 2, Dnipropetrovsk, Ukraine, 49010, tel. +38 (056) 373 15 56, e-mail dnuzt_texmat@ukr.net, \\ ORCID 0000-0002-0613-2544 \\ ${ }^{3}$ Dep. «Materials Technology», Dnipropetrovsk National University of Railway Transport named after Academician \\ V. Lazaryan, Lazaryan St., 2, Dnipropetrovsk, Ukraine, 49010, tel. +38 (056) 373 15 56, e-mail dnuzt_texmat@ukr.net, \\ ORCID 0000-0003-4327-9809
}

\title{
INFLUENCE OF CHEMICAL COMPOUNDS ON THE FORMING OF WELDING ARC
}

Purpose. The purpose of work is a comparative analysis of chemical compounds influence on the process of forming arc welding and condition of its burning. Methodology. A wire with diameter $3 \mathrm{~mm}$ of low carbon steel with contain of carbon $0.15 \%$ was material for electrode. As chemical compounds, which determine the terms of arc welding forming the following compounds were used: kaolin; $\mathrm{CaCO}_{3}$ with admixtures of gypsum up to $60 \%$; $\mathrm{SiO}$ and $\mathrm{Fe}-\mathrm{Si}$ with the iron concentration up to $50 \%$. Researches were conducted using the direct electric current and arc of reverse polarity. As a source of electric current a welding transformer of type PSO-500n was used. On the special stand initial gap between the electrode and metal plate was 1-1.5 mm. The inter electrode space was filled with the probed chemical compound and the electric arc was formed. At the moment of arc forming the values of electric current and arc voltage were determined. After the natural break of electric arc, the final gap value between electrodes was accepted as a maximal value of arc length. Findings. Experimentally the transfer of metal in interelectrode space corresponded to the tiny drop mechanism. According to external signs the relation between maximal arc length and the power of electric current has the form of exponential dependence. Specific power of electric arc at the moment of arc forming per unit of its length characterizes the environment in the interelectrode space. Originality. 1) Based on the analysis of influence of the studied chemical compounds on the formation processes of electric arc the inversely proportional relationship between the power of the electric current and the maximum arc length until the moment of its natural break is defined. 2) Ratio between the maximal arc length and the power of electric current, with the sufficiently high coefficient of correlation is submitted to the exponential dependence. Influence of the compounds under study on the process of electric arc forming is determined using the indexes of degree of the above mentioned correlation. 3) The value of specific power of electric current at the moment of electric arc forming per unit of arc length can be accepted as the parameter, which characterizes the state of interelectrode space environment. Practical value. In the conditions of identical adjusting force of electric current the sequence of location of the studied compounds in the order of increase of their influence on the process of arcing is determined. Minimum influence is observed from kaolin, and maximal one - from $\mathrm{Fe}-\mathrm{Si}$.

Keywords: electric arc; arc length; power of electric current; chemical compound

\section{Introduction}

For the technology of electric arc welding, the initial conditions of electric arc forming to a large Doi 10.15802/stp2014/30824 extent determine the peculiarities of further process of arcing. Taking into account the array of factors, which according to quality indicators in different 
ways influence the conditions of electric arc ignition the state of the interelectrode space environment can be attributed to one of the most important effects [5].

On the other hand, the environment state will become no less important at the stage of stable arcing, defining the conditions of metal transfer through the electrode space. Furthermore, the nature of the molten metal transfer from the electrode to the welding pool itself will stipulate not only the technological characteristics of the electric arc and energy balance, but also the stage of development completion of metallurgical processes when forming the weld connection as a whole $[3,14]$. Taking into account that the influence of interelectrode environment on the arc ignition process is determined by the ionizing power, the location of different substances between electrodes will change the initial conditions of the electric discharge forming $[4,11]$. On this basis, the purposeful influence on the conditions of metal transfer at the moment of electric discharge forming is very important for the technologies of electric arc welding.

\section{Current condition of the problem}

The process of metal transfer through the interelectrode space is to a large extent determined by the initial conditions of the electric arc ignition. The above mentioned metal transfer process can be roughly divided into separate stages. The characteristic conditions of change of the metal aggregate state and its properties are inherent to these stages $[1,6]$. Thus, after formation of liquid, the growth of its volume on the cathode surface takes place until the separation of droplets from the surface and transferring them to the anode.

Taking into account the dependence of the process of droplets forming, their size and shape on the chemical reactions behavior between the substances filling interelectrode space, the combined influence on the ionizing power of environment is difficult to predict $[8,10]$. On the other hand, the formation process of droplets can be confidently considered as dependent on the ratio of the gravitational forces influencing the fluid and force of surface tension of the metal.

The force value of the surface tension of molten metal or alloy is determined by the characteristics of their internal structure, which include the type of crystal lattice, the chemical composition of the alloy. The temperature of the fluid heating and its Doi 10.15802/stp2014/30824 fluidity has certain influence on the specified characteristic.

Thus, for the iron the surface tension coefficient equals to $1.22 \mathrm{~N} / \mathrm{m}$ [6]. Admixtures of alloying chemical elements to the iron lead to its change. For example, the addition to the iron of $18 \% \mathrm{Cr}, 8 \% \mathrm{Ni}$, $1 \% \mathrm{Ti}(\mathrm{H} 18 \mathrm{~N} 9 \mathrm{~T})$ leads to a decrease of the surface tension $(\sigma)$ at the level of $8-10 \%$.

As compared to the influence of chemical composition of the alloy, a mixture of gases of interelectrode space can also influence the level of values $\sigma$, although their influence in most cases is qualitatively different.

Considering the formation of metal droplets of the electrode it can be noted that the main influence is determined by the ratio between the axial force, which arises as a result of so-called pinch effect and the force of surface tension $[4,6]$. The growth of heating temperature of the molten metal is accompanied by a decrease of the surface tension coefficient $[6,9]$.

Accounting the fact that during the first approximation the heating temperature of molten metal is proportional to the strength of welding voltage $(I)$, when the growth $I$, changing the influence of gravitational component reduces the critical size of the droplet (conditions of droplet detachment from the electrode) [6]. At the same time the influence of electromagnetic force [2] including its compressing effect on the molten metal of the weld pool is increasing [2, 12]. After the detachment of droplet from the electrode surface, the process of its movement is starting to depend on the joint action of electrostatic and electrodynamic forces, reactive action of the electric discharge [10].

On the basis of the presented joint influence, the strength increase of electric current is accompanied by breakage of molten metal droplets, which are transferred in the interelectrode space [6, 15]. The presented compound influence on the process of transferring the molten metal during the arc welding can be corrected using various chemical compounds.

\section{Purpose}

Purpose of the article is the comparative analysis of the chemical compounds influence on the process of electric arc forming and the conditions of its burning.

C I. O. Vakulenko, S. O. Plitchenko, D. M. Makarevich, 2014 


\section{Methodology}

The law carbon wire with the diameter $3 \mathrm{~mm}$, of the steel with $0.15 \%$ carbon was used as a material for electrode. As the substances determining the conditions of electric arc formation were used the kaolin; $\mathrm{CaCO}_{3}$ with admixtures of gypsum up to $60 \% ; \mathrm{SiO}_{2}$ and $\mathrm{Fe}-\mathrm{Si}$ if the iron concentration is up to $50 \%$.

The studies were conducted with the use of electric current of constant direction and the arc of reverse polarity. As a source of electric current the welding transformer of the type PSO-500 was used. On the special stand the initial gap between the electrode and metal plate was $1-1.5 \mathrm{~mm}$. Interelectrode space was filled with the studied substance and the electrical discharge was formed.

At the moment of the electric arc ignition the values of electric current and arc voltage were determined. After natural break of electric arc the final size of the space between electrodes is taken as the maximum arc length.

\section{Findings}

Except the dependency of metal heating temperature on the electric current force $[7,10]$ the formation process of molten metal droplets is determined by the joint action of several factors. First of all, the existence of inverse proportion between the heating temperature and the force of metal surface tension shows that the growth $I$ would enhance the fluidity of liquid.

At the same time the rise of electrodynamic influence on the process of droplets formation is observed. The joint influence of the mentioned factors leads to increase in the dispersion degree of molten metal droplets [6].

The process of transferring the molten metal through interelectrode space can be decomposed into successive stages: detachment of the formed droplet from the surface of one electrode and its transferring to another one. Thus, the size of droplets that are detached from the electrode surface will decrease proportionally to the increase of $I$. At the same time the number of droplets that are being transferred through the space between the electrodes per time unit will increase.

When the electric current force is so that the droplets form a continuous chain it is considered reaching the critical conditions that determine the qualitative changes in the nature of metal transfer Doi 10.15802/stp2014/30824 (from the drop to the spray one). Thus, the definition of metal transfer mechanism is of practical importance to assess the influence of the studied substances on the process of electric discharge forming.

The critical value of electric current $\left(I_{c}\right)$ meets the conditions when the diameter of molten metal column reaches about 0.7 of the electrode diameter [6]. On this basis, the value $I_{c}$ is estimated by the ratio:

$$
I_{c}=k \sqrt{\sigma d},
$$

where $k$ and $\sigma-$ are the coefficients of proportionality and surface tension of the metal respectively, $d-$ is the electrode diameter.

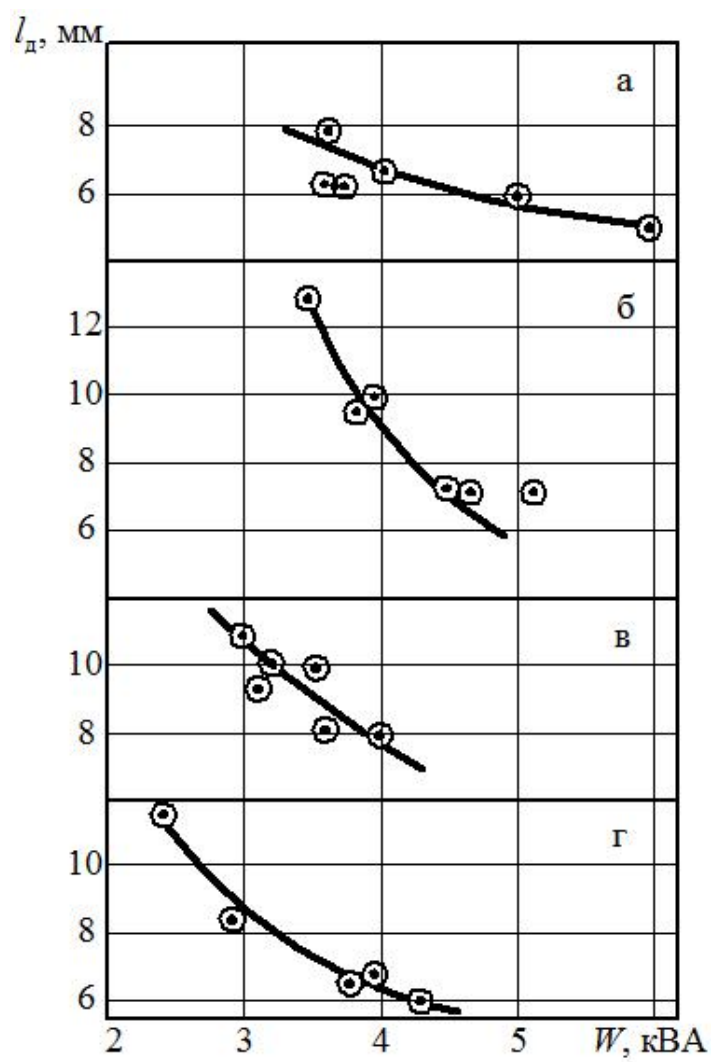

Fig. 1. Influence of kaolin - (a), $\mathrm{SiO}_{2}-$ (b), $\mathrm{Fe}-\mathrm{Si}-$ (c) and $\mathrm{CaCO}_{3}-$ (d) on the ratio between the arc length and the electric current power

Uncertainty of the values $k$ and $\sigma$ can be removed using the known experimental data. So, the surface tension force for iron is $1.22 \mathrm{n} / \mathrm{m}$, and when increasing the content of alloying elements it decreases, reaching the grade for complex alloyed steel KH18N9T for example $1.1 \mathrm{n} / \mathrm{m}$ [6]. Substitut-

(C) I. O. Vakulenko, S. O. Plitchenko, D. M. Makarevich, 2014 
ing in to (1) $\sigma=1.1 \mathrm{n} / \mathrm{m}$, for different electrode diameters: $1-3 \mathrm{~mm}$ and the corresponding values of $I_{c}$ (190-350 A), obtained from the full-scale investigations (according to detachment of molten metal droplets from the electrode surface) for steel KH18N9T the value $k$ was $18.1-18.8 \mathrm{~A} /$ dyne $^{0.5}$.

Taking into account the change range of $\sigma$ for low-carbon steel can be taken $\sigma=1.2 \mathrm{n} / \mathrm{m}$ and $k=18.5 \mathrm{~A} /$ dyne $^{0.5}$. According to ratio (1) it has been determined that for low-carbon steel of electrode with $d=3 \mathrm{~mm}, I_{c}$ should be equal 375-380 A. Comparing with the installation current $200 \mathrm{~A}$ it should be assumed that upon the experimental conditions the metal transfer in the interelectrode space corresponded to the droplet mechanism.

Under conditions of electric current of constant direction with reverse polarity the search for correlations between the maximum arc length $\left(l_{\partial}\right)$ separately for the strength of electric current or arc voltage $(U)$ have shown the need to considerate the influences of $I$ and $U$ at the same time. The results of the constructed dependences for the components under study are presented in the Fig. 1.

According to external characteristics one can talk of inverse relationship between $l_{\partial}$ and electric current capacity ( $W=U I)$. The deviation of dependences $l_{\partial}=f(W)$ from the rectilinear appearance indicates the need to reconstruct them in logarithmic coordinates (Fig. 2).

In the first approximation, the specified dependences are clearly subordinated to relation of the type:

$$
\ln \left(l_{\partial}\right)=A+K \ln (W)
$$

where $A$ and $K$ are the constant characteristics. After transformation the expression (2) takes the form:

$$
l_{\partial} \approx B \frac{e^{A}}{W^{K}}
$$

where $B-$ is a proportionality coefficient.

For each component under study from the graphic solutions of dependences (Fig. 2) the values $A$ and $K$, for the dimension $l_{\partial}$ [mm], $W$ [VA] were determined. Thus, in the order of decreasing the values $A(14.75 ; 13.7 ; 10.5$ and 8.8$)$, the studied components are placed in the corresponding order: $\mathrm{SiO}_{2}, \mathrm{Fe}-\mathrm{Si}, \mathrm{CaCO}_{3}$ and kaolin. The similar pattern of change is also observed for the value $K$ in the specified order $\left(\mathrm{SiO}_{2}, \mathrm{Fe}-\mathrm{Si}, \mathrm{CaCO}_{3}\right.$ and kaolin): $1.5 ; 1.4 ; 1.03$ and 0.817 .

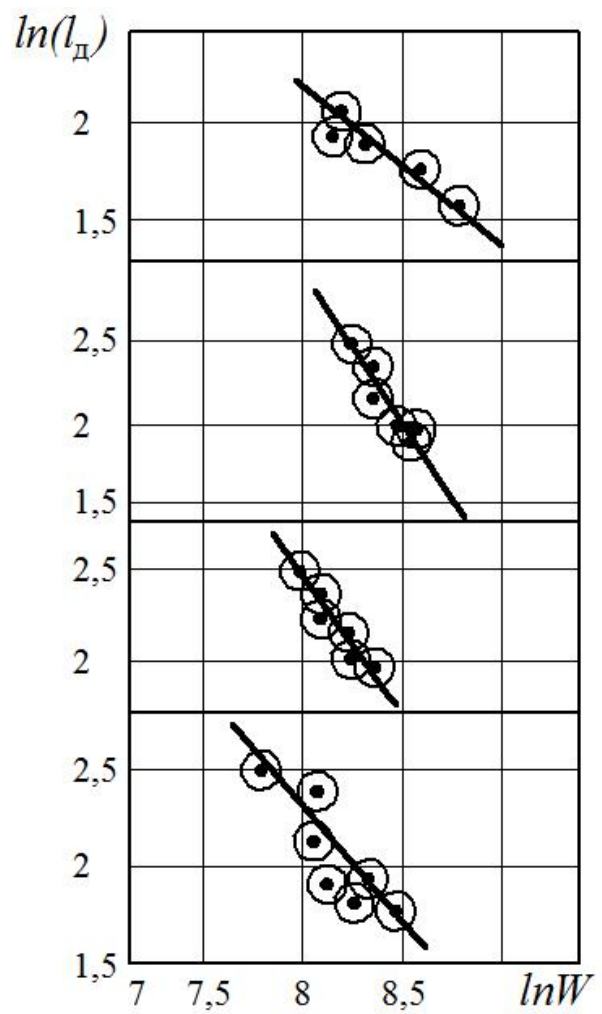

Fig. 2. Dependences $l_{\partial}=f(W)$ for the studied components in the logarithmic coordinates. The identifications are similar to the Fig. 1

For more detailed explanation of the reasons leading to the influence on the formation process of electric arc components in the presented order from $\mathrm{SiO}_{2}$ to kaolin, the additional analysis of the obtained relations was made. Thus, in a first approximation, accounting the known decrease in surface tension force of the iron from the oxygen concentration [6], the presented influence nature (Fig. 1) may be stipulated by the presence of oxygen atoms of different concentration as a result of the dissociation reaction of the studied components. On the other hand, at the initial stages of the arc forming, the increase of electric current strength is accompanied by proportional increase in the metal mass transfer through the interelectrode space $[5,10]$. At the same time, due to the joint action of electric and magnetic fields that appear in the space between electrodes, the axial force determining the mechanical nature of the influence on the molten metal is being formed. The

(C) I. O. Vakulenko, S. O. Plitchenko, D. M. Makarevich, 2014 
voltage that is appearing according to its action represents the pressure voltage.

Under conditions of permanency of the most of factors influencing the formation process of electric arc the specified voltage can be estimated using the power that is appearing $(\rho)$ with the use of dependence [6]:

$$
\rho=k_{\partial} I^{2},
$$

where $k_{\partial}$ - is a coefficient that determines the electrode diameter influence and the electric arc polarity. At the same time, according to the presented dependence the influence of ionizing ability of interelectrode environment is absent. Although using the form of the ratios $l_{\partial}=f(W)$ (Fig. 1) one can still identify the influence peculiarities of the studied substances on the environment of interelectrode space.

Using the electric arc power at the moment of arc forming as the characteristics determining the conditions for its further combustion, the maximum arc length should reflect the state of the interelectrode space environment. Indeed, the analysis of dependences $l_{\partial}=f(W)$ shows that one can quite often observe the change $l_{\partial}$ in a certain range of values for the same levels $W$. In order to try to determine the index, which may allow assessing the influence of the studied substances on the process of arc formation, we use the dependence $l_{\partial}=f(W)$

(Fig. 1). But as an argument we take the value $l_{\partial}$. The next step, after approximation of dependence $W=f\left(l_{\partial}\right)$ with the use of straight lines, the slope coefficient determination allows assessing the degree of influence of the substances under study.

For the range of values $W$ and $l_{\partial}$ (Fig. 1), let us assess the slope coefficient $(C$ ) using the ratio:

$$
C=\frac{\Delta W}{\Delta l_{\partial}},
$$

where $-\Delta W$ and $\Delta l_{\partial}$ are the corresponding change intervals $W$ and $l_{\partial}$.

Taking into account the fact that to each chemical element corresponds its own value of ionization potentials (the first ionization potential, the second and so on [16]) one can make an attempt to assess the specified characteristics of the studied substance $(P)$ with the defined simplification degree.
First of all, to determine $P$ let us use only the first ionization potential of chemical elements whose values are shown in the diagram (Fig. 3).

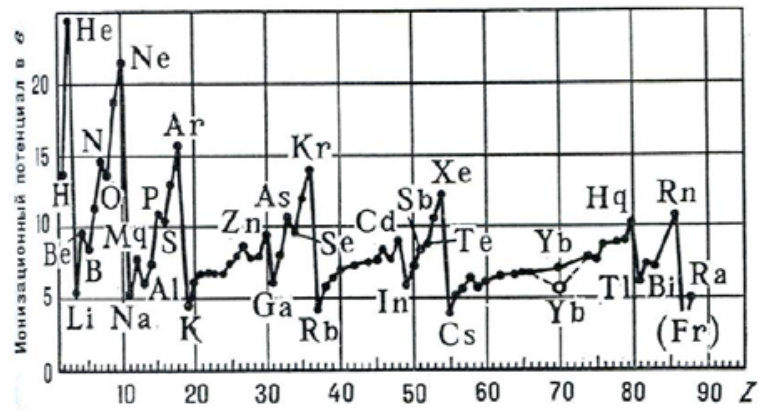

Fig. 3. Value of the first ionization potential of the chemical elements depending on the serial number of the periodic table.

The presented position is stipulated by the fact that during the electric arc formation mainly the extraction of outer (valence) electrons takes place, when the extraction of the electrons closest to the nucleus requires several times more energy $[13,16]$.

In order to take into account the complicated joint influence of different chemical elements presented in the area of electric arc discharge at the same time, it is necessary to make two assumptions.

The first assumption - is an assessment of the $P$ values of the studied substances excluding the energy spent on complete dissociation of molecules or chemical compounds to atomic state. The second assumption - the additive nature of ionization potentials influence of chemical elements forming the molecule or chemical compound in proportion to their number is accepted.

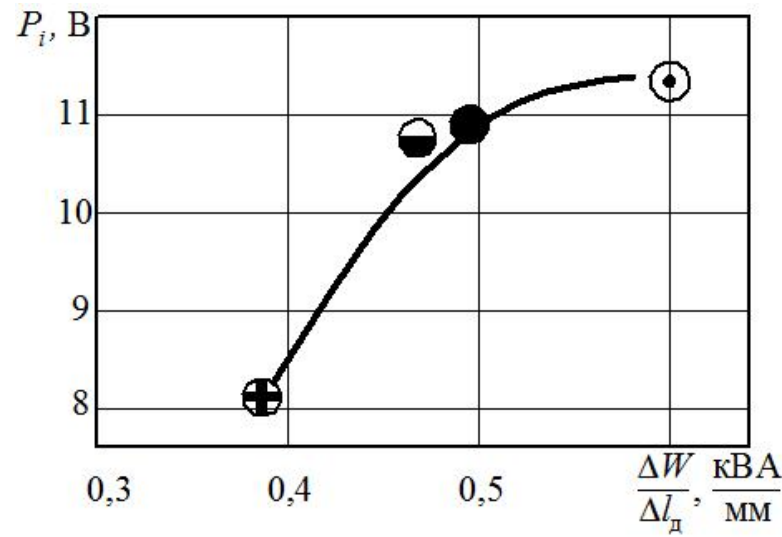

Fig. 4. The ratios between the values $P$ and $C$ for the studied substances ( $\mathbf{O}$ - is a kaolin; - is $\mathrm{SiO}_{2}$;

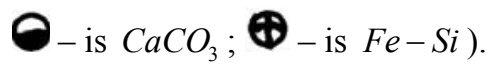

(C) I. O. Vakulenko, S. O. Plitchenko, D. M. Makarevich, 2014 
The influence efficiency of the studied substances on the process of electrical discharge forming that is assessed according to the values $C$ (Fig. 1), in fact, should be connected with the peculiarities of the atomic structure of the chemical elements that form the substances. On the basis of this, one can expect the existence of correlation between the values $C$ and $P$. The result of pair plotting of the specified characteristics is shown in Fig. 4.

Considering the nature of the presented ration one can talk of the proportional relationship between the angular coefficient $(C)$ and the value $P$. If we assume that under certain conditions the formation of electric arc discharge the value $C$ characterizes the substance influence on the process of arc ignition, it is reasonable to expect the existence of relation with the values characterizing the state of interelectrode space. According to the presented dependence as compared to the other substances under study, filling the interelectrode space of $\mathrm{Fe}-\mathrm{Si}$ is accompanied by the electric arc formation at the lowest values of specific power. Around 20\% more of electric current power is necessary to have to enable the arc discharge excitation while filling the interelectrode space and even greater one for kaolin.

\section{Originality and practical value}

1. Based on the influence analysis of the studied substances on the formation processes of electric arc, the inverse relationship between electric current power and the maximum arc length until its natural break was determined.

2. The ratio between the maximum arc length and the electric current power, with a sufficiently high correlation coefficient are subordinated to the exponential dependence. The influence of the studied substances on the electric arc formation is determined using the degree indicators of the proposed relationship.

3. The value of specific power of electric current at the moment of electric arc formation, which is attributed to the arc length, can be taken as a parameter characterizing the state of the interelectrode environment.

Under conditions of the identical adjusting force of electric current the gradation of the studied substances in the order of increase of their influence on the arcing process is determined. Thus, the minimal influence is observed from kaolin, and the maximum one - for $\mathrm{Fe}-\mathrm{Si}$. Using the value $\mathrm{C}$ allows assessing the influence degree of chemical mixture on the formation of electric arc in practice.

\section{Conclusions}

1. Under conditions of the research the metal transfer in the interelectrode space corresponds to the droplet mechanism.

2 . The ratio between the maximum arc length and electric current at the moment of forming the electric discharge for the conditions of inverse polarity, has the form of exponential dependence.

3 . Substance influence on the state of environment of the interelectrode space can be estimated using the ratio of the change speed of electric discharge power at the moment of arc ignition per unit of length.

\section{LIST OF REFERENCE LINKS}

1. Вакуленко, И. А. Морфология структуры и деформационное упрочнение стали / И. А. Вакуленко, В. И. Большаков. - Д. : Маковецкий, 2008. $-196 \mathrm{c}$.

2. Вакуленко, I. О. Структурні перетворення в металі залізничного колеса після дії імпульсів електричного струму / І. О. Вакуленко, В. А. Сокірко, О. С. Баскевич // Вісн. Дніпропетр. нац. ун-ту залізн. трансп. ім. акад. В. Лазаряна. - Д., 2012. - Вип. 42. - С. 160-163.

3. Кривцун, И. В. Модель процессов тепло-, масco- и электропереноса в анодной области и столбе сварочной дуги с тугоплавким катодом / И. В. Кривцун, В. Ф. Демченко, И. В. Крикет // Автомат. сварка. - 2010. - № 6. - C. 3-11.

4. Лесков, Г. И. Электрическая сварочная дуга / Г. И. Лесков. - М. : Машиностроение, 1970. $336 \mathrm{c}$.

5. Приэлектродные процессы в дуговых разрядах / М. Ф. Жуков, Н. П. Козлов, А. В. Пустогаров [и др.]. - Новосибирск : Наука, 1982. - 157 с.

6. Сварка в машиностроении : справ. / под ред. Н. А. Ольшанского - М. : Машиностроение, 1978. - Т. 1. - 504 c.

7. Щербаков, И. П. Исследование изменения субмикрорельефа поверхности медных образцов при пропускании по ним импульсов электричекого тока большой плотности / И. П. Щербаков, Д. В. Чураев, В. Н. Светлов // Журн. техн. физики. - 2004. - № 4. - С. 139-142.

8. Boulos, M. I. Thermal plasmas: Fundamentals and applications / M. I. Boulos, P. Fauchais, 
E. Pfender. - N.-Y. ; London : Plenum press, 1997. - Vol. 1. -454 p.

9. Electric pulse treatment of welding joint of aluminum alloy / I. A. Vakulenko, Yu. L. Nadezdin, V. A. Sokirko [et al.] // Наука та прогрес трансп. Вісник Дніпропетр. нац. ун-ту залізн. трансп. 2013. - № 4 (46). - C. 73-82.

10. $\mathrm{Hu}, \mathrm{J}$. Heat and mass transfer in gas metal arc welding. Pt. I : The arc / J. Hu, H. L. Tsai // Intern. Heat and Mass Transfer. - 2007. - № 50. P. 833-846. doi: 10.1016/j.ijheatmasstransfer.2006. 08.025

11. Investigation of cathode spot behavior of atmospheric argon arcs by mathematical modeling / J. Wendelstorf, G. Simon, I. Decker, H. Wohlfahrt // Proc. 12th Intern. Conf. Gas Discharges \& Their Applications. - Greifswald, 1997. - Vol. 1. P. 62-65.

12. Metal vapour behaviour in gas tungsten arc thermal plasma during welding / M. Tanaka, K. Ya- mamoto, S. Tashiro et al. // Welding in the World. - 2008. - № 11/12. - P. 82-88.

13. Moore, Ch. E. Ionization potentials and ionization limits derived from the analysis of optical spectra / Ch. E Moore. - Washington : NSRDS-NBS 34, 1970. - P. 22.

14. Nestor, O. H. Heat intensity and current density distributions at the anode of high current, inert gas arcs / O. H. Nestor // J. of Appl. Phys. - 1962. vol. 33, № 5. - P. 1638-1648. doi: 10.1063/1. 1728803.

15. Prediction of anode temperatures of free burning arcs / P. Zhu, J. J. Lowke, R. Morrow [et al.] // J. Phys. D : Appl. Phys. - 1995. - № 28. P. 1369-1376. doi: 10.1088/0022-3727/28/7/014.

16. Sanders, N. A. Measurement of anode falls and anode heat transfer in atmospheric pressure high intensity arcs / N. A. Sanders, E. Pfender // J. of Appl. Phys. - 1984. - vol. 55, № 3. - P. 714-722. doi: $10.1063 / 1.333129$.

\section{И. А. ВАКУЛЕНКО ${ }^{1 *}$, С. А. ПЛИТЧЕНКО ${ }^{2}$, Д. Н. МАКАРЕВИЧ ${ }^{3}$}

\footnotetext{
${ }^{1 *}$ Каф «Технология материалов», Днепропетровский национальный университет железнодорожного транспорта имени академика В. Лазаряна, ул. Лазаряна, 2, Днепропетровск, Украина, 49010, тел. +38 (056) 3731556 , эл. почта dnuzt texmat@ukr.net, ORCID 0000-0002-7353-1916

${ }^{2}$ Каф. «Технология материалов», Днепропетровский национальный университет железнодорожного транспорта имени академика В. Лазаряна, ул. Лазаряна, 2, Днепропетровск, Украина, 49010, тел. +38 (056) 3731556 , эл. почта dnuzt_texmat@ukr.net, ORCID 0000-0002-0613-2544

${ }^{3}$ Каф. «Технология материалов», Днепропетровский национальный университет железнодорожного транспорта имени академика В. Лазаряна, ул. Лазаряна, 2, Днепропетровск, Украина, 49010, тел. +38 (056) 37315 56, эл. почта dnuzt_texmat@ukr.net, ORCID 0000-0003-4327-9809
}

\section{ВЛИЯНИЕ ХИМИЧЕСКИХ СОЕДИНЕНИЙ НА ФОРМИРОВАНИЕ ЕЛЕКТРОДУГОВОГО РАЗРЯДА}

Цель. Целью работы является сравнительный анализ влияния химических соединений на процесс формирования электрической дуги и условия ее горения. Методика. Материалом для электрода была низкоуглеродистая проволока диаметром 3 мм из стали с содержанием углерода $0,15 \%$. В качестве соединений, которые определяют условия формирования электродугового разряда, использовали: каолин; $\mathrm{CaCO}_{3}$ с примесями гипса до $60 \%$; $\mathrm{SiO}_{2}$ и $\mathrm{Fe}-\mathrm{Si}$ при концентрации железа до 50 \%. Исследования проводились с использованием постоянного электрического тока и дуги обратной полярности. В качестве источника электрического тока использовали сварочный преобразователь типа ПСО-500. На специальном стенде начальный зазор между электродом и металлической пластиной составлял значение 1-1,5 мм. Межэлектродный промежуток заполняли исследуемым соединением и формировали электрический разряд. В момент возникновения электрической дуги определяли величины электрического тока и напряжения на дуге. После природного разрыва электрической дуги окончательную величину зазора между электродами принимали в качестве максимального значения длины дуги. Результаты. В условиях эксперимента перенос металла в межэлектродном промежутке отвечал капельному механизму. За внешними признаками соотношение между максимальной длиной дуги и мощностью электрического тока имеет вид экспоненциальной зависимости. Удельная мощность электрического дугового разряда в момент формирования дуги на единицу ее длины характеризует состояние среды в межэлектродном промежутке. Научная новизна. 1) На основе анализа влияния исследуемых химических соединений на процессы формирования электрического дугового разряда определена обратно-пропорциональная связь между мощностью электрического тока и максимальной длиной дуги к моменту ее природного разрыва. 2) Соотношение между максимальной длиной дуги и мощно- 
стью электрического тока, с достаточно высоким коэффициентом корреляции, подчиняется экспоненциальной зависимости. Влияние исследуемых соединений на процесс формирования электрического дугового разряда определяется через показатели степени полученного соотношения. 3) Величина удельной мощности электрического тока в момент формирования электрического разряда на единицу длины дуги может быть принята в качестве параметра, который характеризует состояние среды в межэлектродном промежутке. Практическая значимость. В условиях одинаковой установочной силы электрического тока определена последовательность расположения исследуемых химических соединений в порядке увеличения их влияния на процесс горения дуги. Минимальное влияние наблюдается от каолина, а максимальное - от $\mathrm{Fe}-\mathrm{Si}$.

Ключевые слова: электрический дуговой разряд; длина дуги; мощность электрического тока; химическое соединение

\title{
І. О. ВАКУЛЕНКО ${ }^{1 *}$, С. О. ПЛІТЧЕНКО ${ }^{2}$, Д. М. МАКАРЕВИЧ ${ }^{3}$
}

\begin{abstract}
${ }^{1 *}$ Каф. «Технологія матеріалів», Дніпропетровський національний університет залізничного транспорту імені академіка В. Лазаряна, вул. Лазаряна, 2, Дніпропетровськ, Україна, 49010, тел. +38 (056) 37315 56, ел. пошта dnuzt_texmat@ukr.net, ORCID 0000-0002-7353-1916

${ }^{2}$ Каф. «Технологія матеріалів», Дніпропетровський національний університет залізничного транспорту імені академіка В. Лазаряна, вул. Лазаряна, 2, Дніпропетровськ, Україна, 49010, тел. +38 (056) 37315 56, ел. пошта dnuzt_texmat@ukr.net, ORCID 0000-0002-0613-2544

${ }^{3}$ Каф. «Технологія матеріалів», Дніпропетровський національний університет залізничного транспорту імені академіка В. Лазаряна, вул. Лазаряна, 2, Дніпропетровськ, Україна, 49010, тел. +38 (056) 3731556 , ел. пошта dnuzt_texmat@ukr.net, ORCID 0000-0003-4327-9809
\end{abstract}

\section{ВПЛИВ ХІМІЧНИХ РЕЧОВИН НА ФОРМУВАННЯ ЕЛЕКТРОДУГОВОГО РОЗРЯДУ}

Мета. Метою роботи $є$ порівняльний аналіз впливу хімічних речовин на процес запалювання електричної дуги та умови ії горіння. Методика. Матеріалом для електроду був використаний низьковуглецевий дріт діаметром 3 мм із сталі з 0,15 \% вуглецю. В якості речовин, що визначають умови формування електродугового розряду, були використані: каолін; $\mathrm{CaCO}_{3}$ з домішками гіпсу до $60 \%$; $\mathrm{SiO}_{2}$ та $\mathrm{Fe}-\mathrm{Si}$ при концентрації заліза до $50 \%$. Дослідження проводилися при використанні електричного струму постійного напрямку, дуги зворотної полярності. В якості джерела електричного струму був використаний зварювальний перетворювач типу ПСО-500. На спеціальному стенді початковий зазор між електродом та металевою пластиною складав значення 1-1,5 мм. Міжелектродний проміжок заповнювали досліджуваною речовиною і формували електричний розряд. В момент запалювання електричної дуги визначали величини електричного струму та напруги на дузі. Після природного розриву електричної дуги остаточну величину зазору між електродами приймали в якості максимальної довжини дуги. Результати. В умовах експерименту перенос металу в міжелектродному проміжку відповідав краплинному механізму. За зовнішніми ознаками співвідношення між максимальною довжиною дуги і потужністю електричного струму має вигляд експоненціальної залежності. Питома потужність електричного дугового розряду в момент запалення дуги на одиницю їі довжини відображає стан середовища в міжелектродному проміжку. Наукова новизна. 1) На основі аналізу впливу досліджуваних речовин на процеси формування електричного дугового розряду визначений оберненопропорційний зв'язок між потужністю електричного струму і максимальною довжиною дуги до моменту іiі природного розриву. 2) Співвідношення між максимальною довжиною дуги і потужністю електричного струму, з достатньо високим коефіцієнтом кореляції, підпорядковуються експоненціальній залежності. Вплив досліджуваних речовин на процес формування електричного дугового розряду визначається через показники ступеня розглянутого співвідношення. 3) Величина питомої потужності електричного струму в момент формування електричного розряду на одиницю довжини дуги може бути прийнята в якості параметра, що характеризує стан міжелектродного середовища. Практична значимість. За умов однакової установочної сили електричного струму визначена послідовність розташування досліджуваних речовин в порядку збільшення їх впливу на процес горіння дуги. Мінімальний вплив спостерігається з боку каоліну, а максимальний - для $\mathrm{Fe}-\mathrm{Si}$.

Ключові слова: електричний дуговий розряд; довжина дуги; потужність електричного струму; хімічна речовина 


\section{REFERENCES}

1. Vakulenko I.A., Bolshakov V.I. Morfologiya struktury i deformatsionnoye uprochneniye stali [Structure morphology and work hardening of the steel]. Dnipropetrovsk, Makovetskiy Publ., 2008. 196 p.

2. Vakulenko I.O., Sokirko V.A., Baskevych O.S. Strukturni peretvorennia v metali zaliznychnoho kolesa pislia dii impulsiv elektrychnoho strumu [Structural transformations in the rail wheel metal after effect of electric current pulses]. Visnyk Dnipropetrovskoho natsionalnoho universytetu zaliznychnoho transportu imeni akademika V. Lazariana [Bulletin of Dnipropetrovsk National University of Railway Transport named after Academician V. Lazaryan], 2012, issue 42, pp. 160-163.

3. Krivtsun I.V., Demchenko V.F., Kriket I.V. Model protsessov teplo-, masso- i elektroperenosa v anodnoy oblasti i stolbe svarochnoy dugi s tugoplavkim katodom [Model of processes of heat-, mass and electrical transfer in the anode region and the welding arc column with a heat-proof cathode]. Avtomaticheskaya svarka - Automatic welding, 2010, no. 6, pp. 3-11.

4. Leskov G.I. Elektricheskaya svarochnaya duga [Electric welding arc]. Moscow, Mashinostroyeniye Publ., 1970. $336 \mathrm{p}$.

5. Zhukov M.F., Kozlov N.P., Pustogarov A.V. Prielektrodnyye protsessy v dugovykh razryadakh [Nearelectrode processes in the electric arc]. Novosibirsk, Nauka Publ., 1982. 157 p.

6. Olshanskiy N.A. Svarka v mashinostroyenii. Tom 1. [Welding in the mechanical engineering. Volume 1]. Moscow, Mashinostroyeniye Publ., 1978. 504 p.

7. Shcherbakov I.P., Churayev D.V., Svetlov V. N. Issledovaniye izmeneniya submikrorelyefa poverkhnosti mednykh obraztsov pri propuskanii po nim impulsov elektrichekogo toka bolshoy plotnosti [Study of submikrorelief changes of the copper samples surface by passing on them of electric current pulses of large density]. Zhurnal tekhnicheskoy fiziki - Journal of technical physics, 2004, no. 4, pp. 139-142.

8. Boulos M.I., Fauchais P., Pfender E. Thermal plasmas: Fundamentals and applications. Vol. 1. New York; London, Plenum press Publ., 1997. 454 p.

9. Vakulenko I.A., Nadezdin Yu.L., Sokirko V.A. Electric pulse treatment of welding joint of aluminum alloy. Nauka ta prohres transportu. Visnyk Dnipropetrovskoho natsionalnoho universytetu zaliznychnoho transportu - Science and Transport Progress. Bulletin of Dnipropetrovsk National University of Railway Transport, 2013, no. 4 (46), pp. 73-82.

10. Hu J., Tsai H.L. Heat and mass transfer in gas metal arc welding. Pt. I: The arc. International Heat and Mass Transfer, 2007, no. 50, pp. 833-846. doi: 10.1016/j.ijheatmasstransfer.2006.08.025

11. Wendelstorf J., Simon G., Decker I., Wohlfahrt H. Investigation of cathode spot behavior of atmospheric argon arcs by mathematical modeling. Proc. 12th Int. Conf. Gas Discharges \& Their Applications, Greifswald, 1997, vol. 1, pp. 62-65.

12. Tanaka M., Yamamoto K., Tashiro S. Metal vapour behaviour in gas tungsten arc thermal plasma during welding. Welding in the World, 2008, no. 11/12, pp. 82-88.

13. Moore Ch. E. Ionization potentials and ionization limits derived from the analysis of optical spectra. Washington, NSRDS-NBS 34 Publ., 1970. 22 p.

14. Nestor O.H. Heat intensity and current density distributions at the anode of high current, inert gas arcs. Journal of Applied Physics, 1962, vol. 33, no. 5, pp. 1638-1648. doi: 10.1063/1.1728803.

15. Zhu. P., Lowke J.J., Morrow R. Prediction of anode temperatures of free burning arcs. Journal of Physics D: Applied Physics, 1995, no. 28, pp. 1369-1376. doi: 10.1088/0022-3727/28/7/014.

16. Sanders N.A., Pfender E. Measurement of anode falls and anode heat transfer in atmospheric pressure high intensity arcs. Journal of Applied Physics, 1984, vol. 55, no. 3, pp. 714-722. doi: 10.1063/1.333129.

Associate Professor S. V. Proidak, Ph.D. (Tech.); Associate Professor O. O. Chaikovskyi, Ph.D. (Tech.) recommended this article to be published

Received: June 27, 2014

Accepted: Sept. 20, 2014 